\title{
Elderly Falls Prevalence and Associated Factors in Sohag Governorate.
}

\author{
Ahmed Fathy Hamed ${ }^{1}$, Nesreen A. Mohammed ${ }^{1}$, HananY.Aly ${ }^{2}$ \\ ${ }^{1}$ Public Health Department, ${ }^{2}$ NeuropsychiatryDepartment, Faculty of Medicine, Sohag \\ University
}

Received: March 2016 Accepted: June 2016

\begin{abstract}
Population aging is a global challenge experienced by most developed and developing countries. There are diverse deleterious changes produced by aging process resulting in reduction of the effectiveness of various systems which can contribute to the occurrence of falls in the elderly. Elderly falls can have serious consequences and constitute a major cause of morbidity and mortality. Therefore, research is critically needed for establishing effective policies to reduce risk.Objective: This study was conducted to estimate the prevalence of elderly falls and identify associated factors in Sohag Governorate. Methods:A cross-sectional, population-based study conducted from December 2015 to April 2016 in a sample of non-institutionalized elderly people (60 years old or more), living in Sohag governorate.It included 1034participants. A questionnaire was designed to obtain data about history of falls in the previous 12 months and its associated factors.Results:Findings showed that $33.35 \%$ of the studied elderly populationin Sohag Governorate reported that they experienced falls in the previous year.Age, living alone, lighting, presence of stairs and carpets had a highly significant effect (P-value $<0.001$ ) on the incidence of falls among the studied population. Medication use, balance and mobility factors,most of the medical and psychological factors significantly affected the occurrence of falls among the studied population.Conclusion:The prevalence of falls in elderly is relatively high in Sohag Governorate. Identification of factors significantly affecting elderly falls can help in planning public health policies and programs for prevention of falls.
\end{abstract}

Keywords:Elderly; aged, accidental falls, falling, injuries, risk factor.

Corresponding author:Nesreen AM. Ali E-mail: nesreenhammad180@yahoo.comTel: 01225893266

\section{Introduction}

Population aging is a global challenge experienced by most developed and developing countries. There are diverse deleterious changes produced by aging process resulting in reduction of the effectiveness of various systems coupled with the inability to perceive important sensory information. In addition, several chronic diseases can arise with the aging process. These factors can contribute to the occurrence of falls in the elderly ${ }^{1}$.

The risk of falling increases with age. Studies conducted in different countries addressed falls among elderly people, and detect annual frequencies ranging from $6.5 \%$ to $42 \%{ }^{2,3}$. About $30 \%$ of persons over 65 years old and $50 \%$ of those over 80 suffer at least an annual fall worldwide ${ }^{4}$.

Falls are major public health concern for older adults, and with the increasing numbers of elderly population worldwide, research are critically needed for establishing effective policies to reduce risk ${ }^{5}$.

Moreover, falls can have serious consequences and constitute a major cause of morbidity and mortality in the elderly population, since in old age there is an increasing risk of osteoporosis, and 
therefore of bone fractures. Globally, falls are considered one of the main causes of unintentional injury and premature death ${ }^{6,7}$.

The center for disease control and prevention (CDC) reported that falls were the leading cause of injury deaths, and the ninth leading cause of death from all causes, among those 65 years of age and older $^{8,9}$. In 2010, falls were responsible for nearly $80 \%$ of disability resulting from unintentional injuries excluding traffic accidents in adults aged 50 years and over ${ }^{10}$.

Furthermore, over $70 \%$ of the world's aging populations live in developing countries. The proportion will increase in coming decades due to increasing life expectancy in all regions of the world. This demographic change will result in a greater share of the burden of morbidity and mortality due to falls and other chronic conditions in low- and middleincome countries ${ }^{11}$.

There are many possible risk factors for elderly falls ${ }^{12}$. These factors have been classified as extrinsic, which refers to circumstances and environmental fall hazards e.g. housing conditions, family arrangements ${ }^{13-15}$ and intrinsic (or person specific), which related to aging, diseases and effects of medicines ${ }^{16}$. They include physical debility, muscle weakness, unsteady gait, imbalance, impaired cognition $^{17,18}$ and depression ${ }^{19,20}$. There is more risk of falling with a higher disease burden from chronic conditions such as cardiovascular disease and $\operatorname{arthritis}^{21}$. Nutritional deficiency, poor sleep patterns and visual impairment are also associated with increased risk of falling 22 .

Considering that falls can seriously affect the health of the elderly population, in addition to their social and economic implications, this study was conducted to identify the prevalence of elderly falls and factors associated with their occurrence in Sohag governorate.

\section{Participants and Methods}

Study design

The current study was designed as a cross-sectional, population-based study conducted from December 2015 to April 2016 with a sample of noninstitutionalized elderly people (60 years old or more), living in Sohag governorate Falls were defined as involuntary coming to the ground or other lower surface and not as a result of sustaining a violent blow, loss of consciousness and sudden paralysis as in a stroke incident or epileptic seizure. Falls in this study were defined as having history of falling (once at least) in the past one year from the date of interview. The elderly is defined as 60 years old or more.

Study settings and sampling technique

Six districts were chosen randomly by simple random sample from the 12 districts of Sohag governorate to be included in the study to represent the 4 geographical areas of Sohag governorate (north, east, south, and west). From each district two areas were selected randomly covering both urban and rural areas in the districts involved in the study. Houses were selected by systematic random sample from the selected areas (every $10^{\text {th }}$ house) to recruit the elderly people. If no elderly person was found in the $10^{\text {th }}$ house, the following houses were reviewed till finding a house with an elderly person then continuing according to the systematic sampling (every $10^{\text {th }}$ house) from the last reviewed house.

Sample size:

The minimum sample size was 342 individuals as calculated based on the following assumptions: Prevalence of elderly falls from other studies was $(30 \%)^{23,24}$ and a confidence level of $95 \%$.

To obtain more accurate and representative results, the sample size was increased as possible where 1198 elderly persons were interviewed of whom 1034 accepted to participate in the study with a response rate $(86.3 \%)$. The number of participants from each district 
was chosen according to the population size in each district.

The selected districts, urban and rural areas chosen in each district and numbers of respondents are illustrated in following table:

\begin{tabular}{|l|l|l|c|}
\hline \multicolumn{2}{|l|}{ District } & $\begin{array}{l}\text { Selected } \\
\text { areas }\end{array}$ & $\begin{array}{l}\text { Number of } \\
\text { respondents }\end{array}$ \\
\hline \multirow{2}{*}{ Sohag } & Urban & Ashaheed & 82 \\
\cline { 2 - 4 } & Rural & Asalaa & 103 \\
\hline \multirow{2}{*}{ Akhmim } & Urban & $\begin{array}{l}\text { Western } \\
\text { Akhmim }\end{array}$ & 81 \\
\cline { 2 - 4 } & Rural & $\begin{array}{l}\text { Sawamaa } \\
\text { east }\end{array}$ & 109 \\
\hline Tamana & Urban & Almahata & 74 \\
\cline { 2 - 4 } & Rural & Br Kheel & 96 \\
\hline \multirow{3}{*}{ Johaina } & Urban & Sahel Tama & 73 \\
\cline { 2 - 4 } & Rural & $\begin{array}{l}\text { Com El- } \\
\text { Arab }\end{array}$ & 92 \\
\hline Almonshah & Urban & $\begin{array}{l}\text { East } \\
\text { Johaina }\end{array}$ \\
\cline { 2 - 4 } & Rural & Enibs & 64 \\
\cline { 2 - 4 } & Rural & Almonshah & 76 \\
\hline
\end{tabular}

\section{Data Collection}

A questionnaire was designed to obtain data about history of falls in the previous 12 months and factors associated with their occurrence. Data were collected via face to face interview with respondents.

The questionnaire included five categories of factors associated with elderly falls: socio-demographic and environmental factors, medications use and types used, balance and mobility factors, sensory and neuromuscular factors and medical and psychological factors. Of these factors, environmental factors, residence, living alone and using assistive device were considered as extrinsic factors and other factors included in the questionnaire were considered as intrinsic factors.

The outcome variable is defined using two key questions in the study questionnaire. Participants were first asked about history of falls in the last 12 months, if the response was "yes", they were then asked about the effect of the fall.

Inclusion criteria included being at least 60 years old and accepting to answer the questionnaire and participate in the study. Exclusion criteria included individuals who can't speak (mute) or listen (deaf), those who refuse to participate in the study and emotionally unstable persons.

The respondents were assured of confidentiality and provided with an explanation about the purpose of the study and the importance of their contribution. They gave verbal consent to participate in the study.

Data analysis and presentation:

SPSS program version 16 was used for data entry and analysis. Qualitative data were presented as numbers and percentages. The associations between variables and falls that occurred in the past 12 months were analyzed by the Chi-squared test.

\section{Ethical consideration}

Approval of the Research Ethics Committee of Faculty of Medicine, Sohag University was secured and informed consent after explaining the aim of the study was obtained from all participants in the study. The questionnaires used in data collection were anonymous and confidentiality of data was assured.

\section{Results}

Data was presented based on the outcome variable and the predetermined categories of the study questionnaire.

Figure (1) shows that the prevalence of elderly falls in the previous 12 months among the participating elderly population in Sohag Governorate was 33.35 per 100 of the respondents. The relationship between falls and environmental and sociodemographic characteristics of the studied population is summarized in table (1). $73.4 \%$ of respondents aged 90 years or older and more than half $(52.4 \%)$ of respondents in the age group (80- years) reported that they experienced falls in the last year. Younger respondents experienced lower falling rates. 
More than half $58.3 \%$ of those who were living in houses with stairs reported that they suffered falls in the previous year. $72.8 \%$ of elderly lived in houses with poor lightening reported previous year falls. As regards presence of carpets and living alone, 47.6 of those lived in houses where carpets were present and $64.2 \%$ of respondents reported that they lived alone had a history of falls in the previous 12 months. These factors had a highly significant effect $(\mathrm{P}$-value $=$ 0.000 ) on the occurrence of falls among the studied population. On the other hand, sex, residence and type of flooring didn't have a significant effect on the prevalence of falls.

Table (2) presents medication use, balance and mobility and their relationship with falls among the studied population. As regards medication use, $41.5 \%$ of respondents who reported medications use experienced falls in the last year. Medications used by respondents who suffered falls in the previous year are illustrated in figure (2) where $39.1 \%$ reported that they used sedative and hypnotic drugs, $24 \%$ used diuretics, $19.4 \%$ used neuroleptic drugs and $14 \%$ used antihypertensive drugs.

Regarding balance and mobility factors, $41.8 \%$ of respondents who suffered dizziness upon standing and $41.7 \%$ of respondents who reported lower extremities weakness reported that they suffered falls in the previous year. Furthermore, the majority of participants who were handicapped and participants suffered impaired balance and gait deficit had a history of falls in the previous 12 months. Medication use, balance and mobility factors significantly affected falling among the studied population $(\mathrm{p}<0.001)$.

As illustrated in table (3), more than half $(53.1 \%)$ of respondents who had urinary incontinence and $41.8 \%$ of those suffering nocturia reported previous year falls with both factors had a highly significant effect on falling among the studied population. In addition, most of the medical and psychological factors significantly affected the occurrence of falls among the studied population $(\mathrm{p}<0.001)$. On the other hand, there was no significant effect of visual impairment on history of falling in the previous 12 months $(\mathrm{p}=0.124)$.

Figure (3) shows effects sustained after falling among respondents experienced falls in the previous year. $31.4 \%$ of them suffered bruises as a result of a fall, $26 \%$ suffered reduced activity and 20\% suffered fractures.

\section{Discussion}

Falls are among the leading causes of morbidity and mortality for elderly population. Falls can result in sustaining different types of injuries. The loss of confidence caused by falls can result in reduced physical activity, more dependency, and social withdrawal ${ }^{25}$.

Results of the current study revealed that 33.35 per 100 of the studied population reported that they suffered falls in the previous year. This finding is near the results of a study conducted by Cumming R. ${ }^{26}$ who reported that about $30 \%$ of people aged over 65 years and living in the community fall at least once in a year. Another study conducted by Ro D., et $\mathrm{al}^{27}$ found that approximately $30 \%$ of the older adults fall once, and 10\%-20\% fall two or more times.

On the other hand, a population-based study conducted by Chan K., et $\mathrm{al}^{28}$ to determine the prevalence rate of falls among the elderly population in Singapore revealed that the prevalence was $17.2 \%$ and another study conducted by $\mathrm{Chu}$ W., et al ${ }^{29}$ in Hong Kong found that the prevalence of falling was $19.3 \%$. In another study conducted by Azidah A $\mathrm{K}$., et $\mathrm{al}^{30}$ in Malaysia, the prevalence of falls among elderly diabetes was $18.8 \%$. The current study revealed a highly significant effect $(\mathrm{P}<0.001)$ of age, living alone and some environmental hazards e.g. presence of stairs, carpets and 
lighting on the occurrence of falls among the studied population. On the other hand, sex, residence and type of flooring didn't have a significant effect on the prevalence of falls. These findings are in agreement with Matteo C. et $\mathrm{al}^{25}$ who conducted a study to determine the prevalence of falls and related risk factors in older population, Italy and found that age and environmental hazards significantly affected the prevalence of falls while sex had no significant effect.

On the other hand, Almawlawi E., et $\mathrm{al}^{24}$ conducted a study in Qatar to identify the prevalence and risk factors for falls among the elderly in primary healthcare centers and found that sex significantly affected the occurrence of falling among participants while environmental hazards and living alone didn't.

In addition, results revealed that medication use, balance and mobility factors significantly affected falling among the studied population $(\mathrm{P}<0.001)$. These findings are in line with other studies reported that psychotropic medications including antidepressants, anxiolytics/hypnotics, drugs used in dementia, and antipsychotics have been shown to increase the risk of falling ${ }^{31,32}$.

Other studies conducted by Di Fabio R., et $\mathrm{al}^{33}$ and Kristinsdottir E., et $\mathrm{al}^{34}$ showed significant effect of vestibular dysfunction with vertigo and dizziness on elderly falls.

The majority of participants who suffered gait deficit had a history of falls in the previous 12 months and this factor significantly affected falling among the studied population $(\mathrm{P}<0.001)$. This is in agreement with Matteo $\mathrm{C}$. et $\mathrm{al}^{25}$ and Almawlawi E., et $\mathrm{al}^{24}$ who found that gait problems had a highly significant effect on the occurrence of falls among the studied population.

Studies reported that urinary incontinence, activities of daily living impairment, and depression had a highly significant effect on falling among the studied population which is consistent with the findings of the current study $^{24,35,36}$

Moreover, results revealed a highly significant effect of history of stroke on elderly falls which is consistent with the study conducted by Matteo C. et $\mathrm{al}^{25}$ and demonstrates the high prevalence of falls and fall-related injuries among stroke survivors.

Regarding effects sustained after a fall among respondents experienced falls in the previous year, $31.4 \%$ of them suffered bruises as a result of a fall, $26 \%$ suffered reduced activity and 20\% suffered fractures. These findings are inconsistent with the results of a study conducted by Kannus P. and Karim M. ${ }^{37}$ who reported that about $70 \%$ of fallinduced injuries sustained by elderly people were bone fractures. Furthermore, another study conducted by Egide K., José M., ${ }^{38}$ showed that the most prevalent fall related injuries among older adults were injuries of the hip, back injuries, and broken ankles. Other injuries that were less frequent included bruises, cuts and grazes.

\section{Limitations of the study}

The cross sectional nature of the data is considered a limitation in terms of interpreting causal association. The burden of falls and their effect on the quality of life of elderly population were not covered by the current study and further research is needed to provide information in this area.

\section{Conclusion}

The present study shows that the prevalence of elderly falls in the previous 12 months was $33.35 \%$ of the studied elderly population in Sohag Governorate. In addition, the study presents categories of the elderly population who are more prone to falls through the identification of factors significantly affected this outcome. Age, living alone, most of the environmental factors, medication use significantly affected falls occurrence 
among the studied elderly population.In addition, balance and mobility factors, sensory and neuromuscularfactors and most of medical and psychological factors addressed in the current study had a highly significant effect on elderly falls. These findings can help in the planning of public health policies and programs needed for the prevention of falls.

\section{References}

1. Oliveira FS, Santos SSC, Kerber NPC, Francioni FF, VD. C. Scientific production about the environmental risk factors for falls in the elderly: integrative review. J Nurs UFPE on line. 2015;9(2):759-67.

2. Gang L., Sufang J., Ying S. The incidence status on injury of the community-dwelling elderly in Beijing. Chi J Prev Med. 2006;40(1):37.

3. Wannian L., Ying L., Xueqing W., Chin J. An epidemiological study on injury of the community-dwelling elderly in Beijing. Dis Control Prev. 2004; 8(6):489-92.

4. Calvalcante ALP., Aguiar JB., Gurgel LA. Fatores associados a quedas em idosos em um bairro de Fortaleza, Ceará. Rev Bras Geriatr Gerontol 2012;15(1):137-46.

5. Stewart J., Kowal P., Hestekin H., O’Driscoll T., Peltzer K., Yawson A. Prevalence, risk factors and disability associated with fall-related injury in older adults in low- and middleincomecountries: results from the WHOStudy on global AGEing and adult health (SAGE). BMC Medicine. 2015;13(147):1-12.

6. Murray C., Vos T., Lozano R., Naghavi M., Flaxman A.D, Michaud C. Disability-adjusted life years (DALYs) for 291 diseases and injuries in 21 regions, 1990-2010: a systematic analysis for the Global Burden of Disease Study 2010. Lancet. 2012;227:380:2198.
7. Bischoff-Ferrari HA., Orav EJ., wsonHughes B. Effect of cholecalciferol plus calcium on falling in ambulatory older men and women: a 3-year randomized controlled trial. Archives of Internal Medicine. 2006;166:424-30.

8. Clemson L., Cumming RG., Kendig H., Swann M., Heard R. The effectiveness of a community-based program for reducing the incidence of falls in the elderly: a randomized trial. J Am Geriatr Soc. 2004;52.

9. Michael YL., Lin JS., Whitlock EP., Gold R., Fu R., O'Connor EA. Interventions to Prevent Falls in Older Adults: An Updated Systematic Review. Evidence Synthesis No. 80. AHRQ Publication No. 11-05150-EF-1. Rockville, MD: Agency for Healthcare Research and Quality. December 2010. 10. Institute for Health Metrics and Evaluation. GBD Compare. http://www.healthmetricsandevaluation.org/g bd. Accessed 25 May 2015.

11. Beard JR., Biggs S., Bloom DE., Fried LP., Hogan P., Kalache A. Global population ageing: peril or promise? Geneva: World Economic Forum 2012.

12. Kwan MM., Close JC., Wong AK., Lord SR. Falls incidence, risk factors, and consequences in Chinese older people: a systematic review. J Am Geriatr Soc. 2011;59:536-43.

13. Siqueira FV., Facchini LA., Piccini RX., Tomasi E., Thumé E., Silveira DS. Prevalência de quedas em idosos e fatores associados. Rev Saúde Pública. 2007;41(5):749-56.

14. Motta LB., Aguiar AC., Coutinho ESF., Huf G. Prevalência e fatores associados a quedas em idosos em um município do Rio de Janeiro. Rev Bras Geriatr Gerontol. 2010;13(1):83-91.

15. Axer H., Axer M., Sauer H., Witte OW., Hagemann G. Falls and gait disorders in geriatric neurology. Clinical Neurology and Neurosurgery. 2010;112(4):265-74.

16. Fabrício SCC., Rodrigues RAP., Costa Junior ML. Causas e 
consequências de quedas de idosos atendidos em hospital público. Rev Saúde Pública. 2004;38(1):93-9.

17. Rubenstein LZ. Falls in older people: epidemiology, risk factors and strategies for prevention. Age Ageing. 2006;35:37-41.

18. Fang X., Shi J., Song X., Mitnitski A., Tang Z., Wang C. Frailty in relation to the risk of falls, fractures, and mortality in older Chinese adults: results from the Beijing Longitudinal Study of Aging. J Nutr Health Aging. 2012;16:903-7.

19. Kvelde T., McVeigh C., Toson B., Greenaway M., Lord SR., Delbaere K. Depressive symptomatology as a risk factor for falls in older people: systematic review and meta-analysis. J Am Geriatr Soc. 2013;61:694-706.

20. Halil M., Ulger Z., Cankurtaran M., Shorbagi A., Yavuz BB., Dede D. Falls and the elderly: is there any difference in the developing world? A cross-sectional study from Turkey. Arch Gerontol Geriatr 2006;43:351-9.

21. Yu PL., Qin ZH., Shi J., Zhang J., Xin MZ., Wu ZL. Prevalence and related factors of falls among the elderly in an urban community of Beijing. Biomed Environ Sci. 2009;22:179-87.

22. Boutin T., Kergoat MJ., Latour J., Massoud F., Kergoat H. Vision in the global evaluation of older individuals hospitalized following a fall. J Am Med Dir Assoc 2012;13(e115):187-9.

23. Gumming R. Epidemiology of medication-related falls and fractures in the elderly. Drugs \& Aging. 1998;12(11):43-53.

24. Almawlawi E., AI Ansari A., Ahmed A. Prevalence and Risk Factors for Falls Among the Elderly in Primary Healthcare Centers (PHC) in Qatar. Qatar medical journal. 2011;20(1):12-7.

25. Matteo C., Francesco L., Sergio T., Graziano O., Fabrizia L., Roberto B. Prevalence and Risk Factors for Falls in an Older Community-Dwelling Population. Journal of Gerontology:
MEDICAL SCIENCES 2002;57A(11):M722-M6.

26. Cumming R. G. Epidemiology of medication-related falls and fractures in the elderly. Epidemiology. 1998;12(1):43-6.

27. Ro D., Shadden B S., Blake HR, Powers M. Exercise intervention designed to improve strength and dynamic balance among communitydwelling older adults. The Journal of Aging and Physical Activity. 2005;13:198-209.

28. Chan K., Pang W S., Ee C H. , Ding Y Y., Choo P. Epidemiology of falls among the elderly community dwellers in Singapore. Singapore Medical Journal. 1997;38(10):427-31.

29. Chu W., Chi I., Chiu A. Incidence and predictors of falls in the Chinese elderly. Annals of the Academy of Medicine Singapore. 2005;34(1):60-72.

30. Azidah A K., Hasniza H., Zunaina E. Prevalence of Falls and Its Associated Factors among Elderly Diabetes in a Tertiary Center,Malaysia. Hindawi Publishing Corporation. Current Gerontology and Geriatrics Research; 2012.

31. Woolcott JC., Richardson KJ., Wiens MO. Metaanalysis of the impact of 9 medication classes on falls in elderly persons. Archives of Internal Medicine. 2009;169(21):1952-60.

32. Hartikainen S., Lonnroos E., Louhivuori K. Medication as a risk factor for falls: critical systematic review. Journal of Gerontology: MEDICAL SCIENCES. 2007;62(10):1172-81.

33. Di Fabio R., Emasithi A., Greany JF., Paul S. Suppression of the vertical vestibuloocular reflex in older persons at risk of falling. Acta Otolaryngologica (Stockh). 2001;121:707-14.

34. Kristinsdottir E., Nordell E., Jarnlo GB., Tjader A., Thorngren KG., Magnusson M. Observation of vestibular asymmetry in a majority of patients over 50 years with fall-related wrist fractures. 
Acta Oto-Laryngologica. 2001;121:4815.

35. Gillespie LD., Gillespie WJ., Robertson MC., Lamb SE., Cumming RG., Rowe BH. Interventions for preventing falls in elderly people. Cochrane Database of Systematic Reviews. 2003;4:CD000340.

36. Dunlop DD., Manheim LM., Sohn MW. Incidence of functional limitation in older adults: the impact of gender, race, and chronic conditions. Archives of Physical Medicine and Rehabilitation. 2002;83:964-71.
37. Kannus P., Karim M. Prevention of falls and subsequent injuries in elderly people: A long way to go in both research and practice. The Journal of the Canadian Medical Association. 2001;4(5):165.

38. Egide K., José M. Epidemiology of and risk factors for falls among the community-dwelling elderly people in selected districts of Umutara province, Republic of Rwanda.: University of the Western Cape.; 2005. 
Table (1): Environmental and sociodemographic factors and their relationship with falls in the studied population $(\mathrm{N}=1034)$

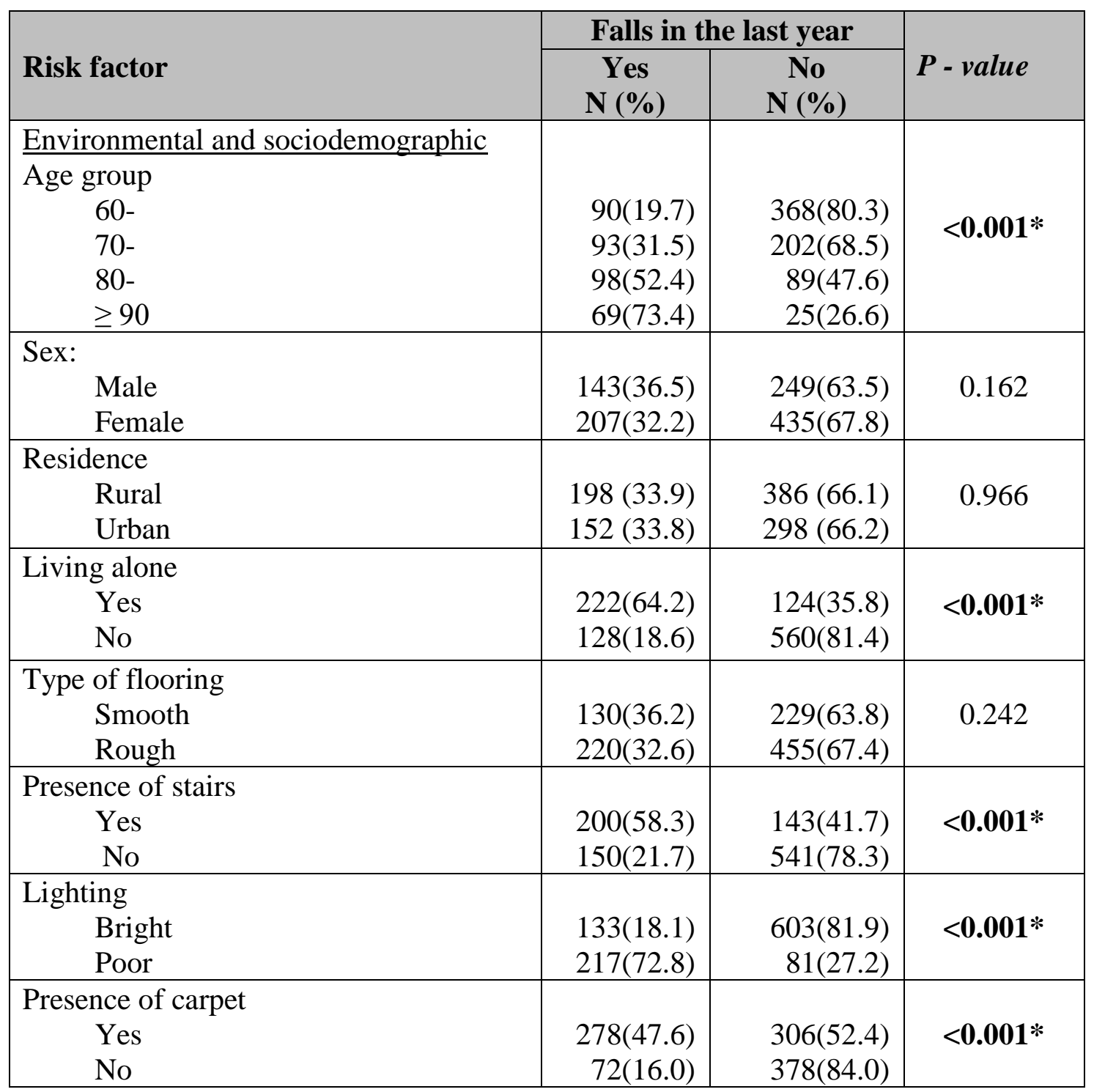


Table (2): Medication use, balance and mobility and their relationship with falls in the studied population $(\mathrm{N}=1034)$.

\begin{tabular}{|c|c|c|c|}
\hline \multirow[b]{2}{*}{ Risk factor } & \multicolumn{2}{|c|}{ Falls in the last year } & \multirow[t]{2}{*}{$P$ - value } \\
\hline & $\begin{array}{c}\text { Yes } \\
\mathbf{N}(\%)\end{array}$ & $\begin{array}{c}\text { No } \\
\mathbf{N}(\%)\end{array}$ & \\
\hline $\begin{array}{l}\text { Medication use } \\
\text { Use of medicines } \\
\text { Yes } \\
\text { No }\end{array}$ & $\begin{array}{r}348(41.5) \\
2(1.0) \\
\end{array}$ & $\begin{array}{r}490(58.5) \\
194(99)\end{array}$ & $<0.001 *$ \\
\hline $\begin{array}{l}\text { Balance and mobility } \\
\text { Dizziness upon standing } \\
\text { Yes } \\
\text { No }\end{array}$ & $\begin{array}{l}198(41.8) \\
152(27.1)\end{array}$ & $\begin{array}{l}276(58.2) \\
408(72.9)\end{array}$ & $<0.001 *$ \\
\hline $\begin{array}{c}\text { Physical exercise } \\
\text { Yes } \\
\text { No } \\
\end{array}$ & $\begin{array}{r}122(23) \\
228(45.2) \\
\end{array}$ & $\begin{array}{l}408(77.0) \\
276(54.8) \\
\end{array}$ & $<0.001 *$ \\
\hline $\begin{array}{l}\text { Lower extremities weakness } \\
\text { Yes } \\
\text { No }\end{array}$ & $\begin{array}{l}187(41.7) \\
163(27.8)\end{array}$ & $\begin{array}{l}261(58.3) \\
423(72.2)\end{array}$ & $<0.001 *$ \\
\hline $\begin{array}{c}\text { Impaired balance } \\
\text { Yes } \\
\text { No } \\
\end{array}$ & $\begin{array}{l}185(88.9) \\
165(20.0) \\
\end{array}$ & $\begin{array}{r}23(11.1) \\
661(80.0) \\
\end{array}$ & $<0.001 *$ \\
\hline $\begin{array}{c}\text { Gait deficit } \\
\text { Yes } \\
\text { No }\end{array}$ & $\begin{array}{l}185(89.4) \\
165(20.0)\end{array}$ & $\begin{array}{r}22(10.6) \\
662(80.0)\end{array}$ & $<0.001 *$ \\
\hline $\begin{array}{c}\text { Handicapped } \\
\text { Yes } \\
\text { No } \\
\end{array}$ & $\begin{array}{l}101(98.1) \\
249(26.7)\end{array}$ & $\begin{array}{r}2(1.9) \\
682(73.3) \\
\end{array}$ & $<0.001 *$ \\
\hline $\begin{array}{l}\text { Orthostatic hypotension } \\
\text { Yes } \\
\text { No } \\
\end{array}$ & $\begin{array}{l}207(51.0) \\
143(22.8) \\
\end{array}$ & $\begin{array}{l}199(49.0) \\
485(77.2)\end{array}$ & $<0.001 *$ \\
\hline $\begin{array}{l}\text { Use assistive device } \\
\text { Yes } \\
\text { No }\end{array}$ & $\begin{array}{l}180(61.2) \\
170(23.0)\end{array}$ & $\begin{array}{l}114(38.8) \\
570(77.0)\end{array}$ & $<0.001 *$ \\
\hline
\end{tabular}


Table (3): Sensory, neuromuscular, medical and psychological factors and their relationship with falls in the studied population $(\mathrm{N}=1034)$

\begin{tabular}{|c|c|c|c|}
\hline \multirow[b]{2}{*}{ Risk factor } & \multicolumn{2}{|c|}{ Falls in the last year } & \multirow[b]{2}{*}{$P$ - value } \\
\hline & $\begin{array}{c}\text { Yes } \\
\mathbf{N}(\%) \\
\end{array}$ & $\begin{array}{c}\text { No } \\
\mathbf{N}(\%) \\
\end{array}$ & \\
\hline $\begin{array}{c}\text { Sensory and neuromuscular } \\
\text { Urinary incontinence } \\
\text { Yes } \\
\text { No }\end{array}$ & $\begin{array}{l}217(53.1) \\
133(21.3)\end{array}$ & $\begin{array}{l}192(46.9) \\
492(78.7)\end{array}$ & $<0.001 *$ \\
\hline $\begin{array}{l}\text { Nocturia } \\
\text { Yes } \\
\text { No }\end{array}$ & $\begin{array}{l}226(41.8) \\
124(25.2)\end{array}$ & $\begin{array}{l}315(58.2) \\
369(74.8)\end{array}$ & $<0.001 *$ \\
\hline $\begin{array}{l}\text { Medical and psychological } \\
\text { Visual impairment } \\
\text { Yes } \\
\text { No }\end{array}$ & $\begin{array}{r}263(35.3) \\
87(30.2) \\
\end{array}$ & $\begin{array}{l}483(64.7) \\
201(69.8) \\
\end{array}$ & 0.124 \\
\hline $\begin{array}{l}\text { Arthritis } \\
\text { Yes } \\
\text { No }\end{array}$ & $\begin{array}{l}212(51.5) \\
138(22.2)\end{array}$ & $\begin{array}{l}200(48.5) \\
484(77.8)\end{array}$ & $<0.001 *$ \\
\hline $\begin{array}{c}\text { History of stroke } \\
\text { Yes } \\
\text { No }\end{array}$ & $\begin{array}{l}133(98.5) \\
217(24.1) \\
\end{array}$ & $\begin{array}{r}2(1.5) \\
682(75.9) \\
\end{array}$ & $<0.001 *$ \\
\hline $\begin{array}{c}\text { Depression } \\
\text { Yes } \\
\text { No }\end{array}$ & $\begin{array}{l}131(67.9) \\
219(26.0)\end{array}$ & $\begin{array}{r}62(32.1) \\
622(74.0) \\
\end{array}$ & $<0.001 *$ \\
\hline $\begin{array}{l}\text { Cognitive impairment } \\
\text { Yes } \\
\text { No }\end{array}$ & $\begin{array}{l}135(88.2) \\
215(24.4) \\
\end{array}$ & $\begin{array}{r}18(11.8) \\
666(75.6) \\
\end{array}$ & $<0.001 *$ \\
\hline $\begin{array}{c}\text { Impaired ADL } \\
\text { Yes } \\
\text { No } \\
\end{array}$ & $\begin{array}{r}263(41.6) \\
87(21.6) \\
\end{array}$ & $\begin{array}{l}369(58.4) \\
315(78.4) \\
\end{array}$ & $<0.001 *$ \\
\hline
\end{tabular}




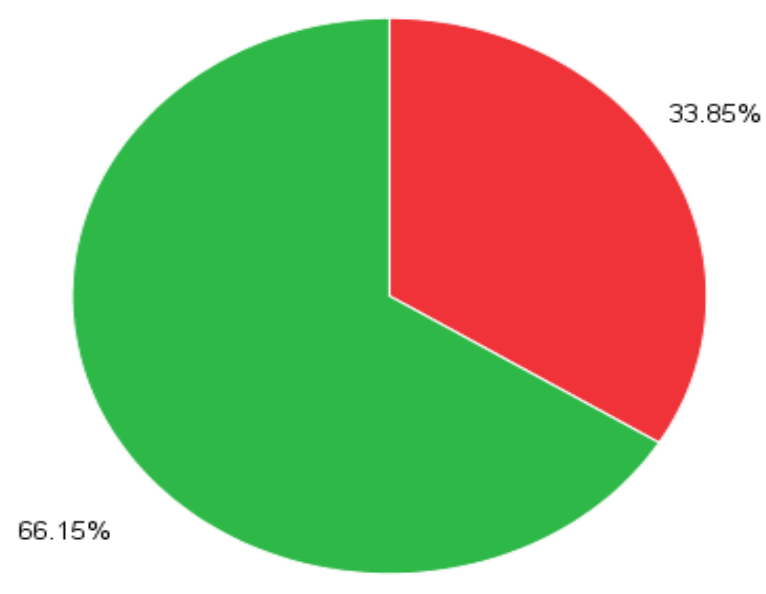

Figure (1): Prevalence of falls among studied population in the previous year in Sohag Governorate (N=1034)

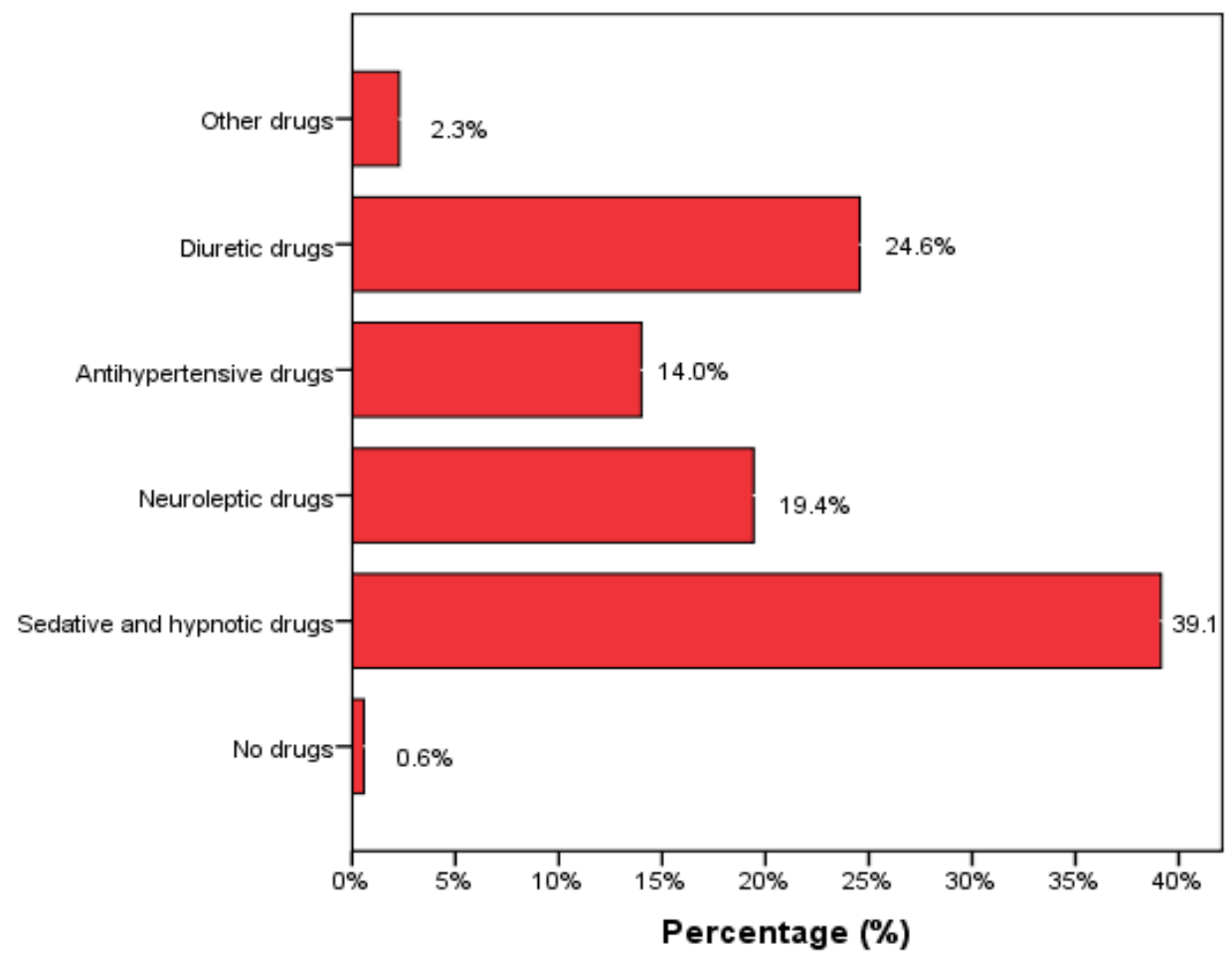

Figure (2): Medications used by participants experienced falls in the previous year $(\mathrm{N}=350)$ 


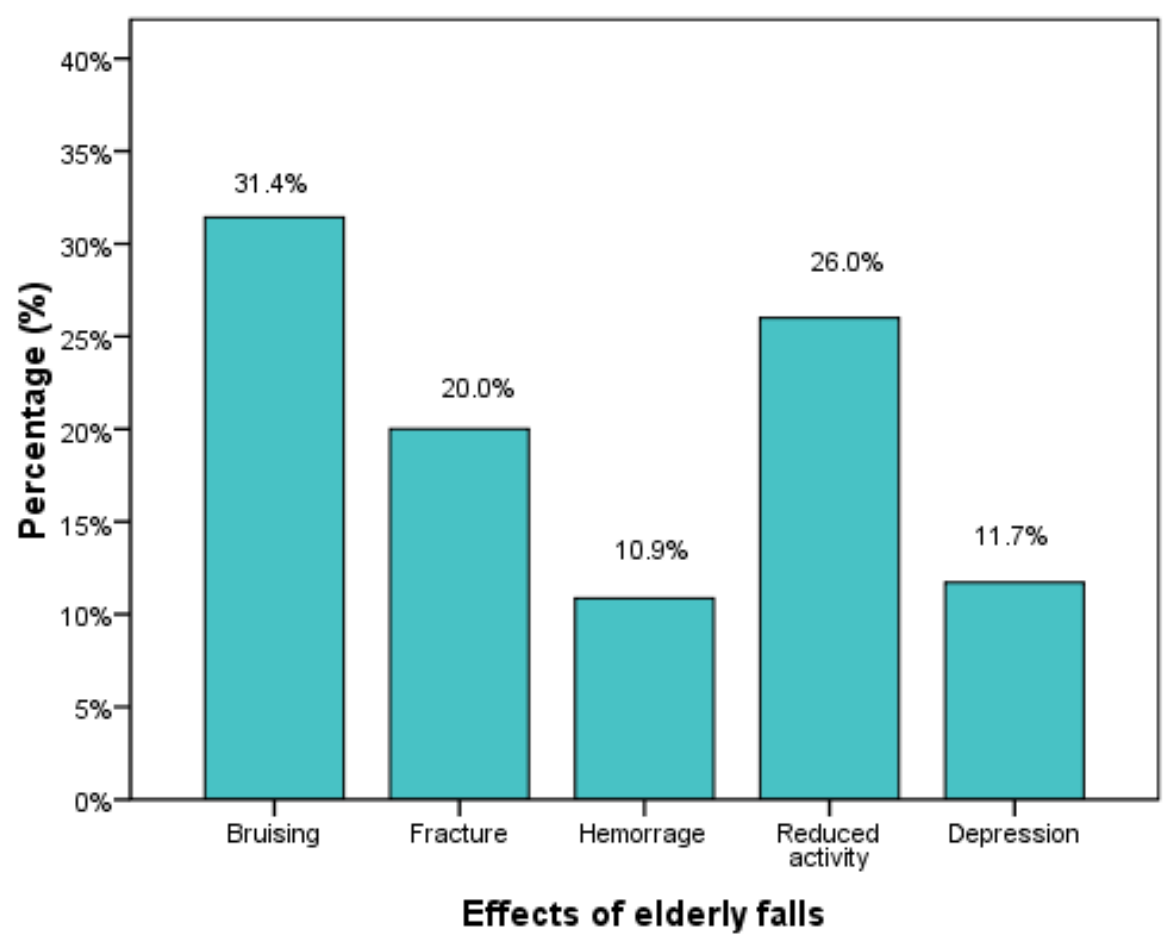

Figure (3): Post-fall sequelae among respondents who experienced falls in the previous year $(\mathrm{N}=350)$ 